\title{
Long-term monitoring of a hyacinth macaw Anodorhynchus hyacinthinus (Psittacidae) roost in the Pantanal, Brazil
}

\author{
Pedro Scherer-Neto ${ }^{1}$, Neiva Maria Robaldo Guedes ${ }^{2,3}$, \\ Maria Cecília Barbosa Toledo ${ }^{4, *}$ \\ ${ }^{1}$ Natural History Museum Capão da Imbuia, Rua Benedito Conceição 407, Curitiba-PR, 82810-150, Brazil \\ ${ }^{2}$ Environment and Regional Development Postgraduate Program, Anhanguera-Uniderp University, Campo Grande-MS, \\ 79003-010, Brazil \\ ${ }^{3}$ Hyacinth Macaw Institute, Campo Grande-MS, 79051-660, Brazil \\ ${ }^{4}$ Bioscience Institute, University of Taubaté, Av. Tiradentes 500, Taubaté-SP, 12030-180, Brazil
}

\begin{abstract}
The hyacinth macaw Anodorhynchus hyacinthinus is the world's largest parrot species and is currently listed as Vulnerable by the IUCN. This species commonly flocks in collective roost sites. We monitored a group of hyacinth macaws that has used a single roost site on a ranch with traditional, extensive cattle management in the Pantanal, Brazil, for over $50 \mathrm{yr}$. We analyzed $15 \mathrm{yr}$ of monitoring data on the use of this roost site. We used simultaneous counts $(\mathrm{n}=37)$, where individuals flying to the roost site were counted, and also counted pairs in nests. The results indicate that in 2001 there were 234 (mean no. of ind.; $95 \% \mathrm{CI}=55$ ) macaws in the roost; $15 \mathrm{yr}$ later $708(95 \%$ CI $=142)$ were registered. The highest number of macaws registered was in the years of 2013 and 2015, when >1000 ind. were observed at the ranch. The model showed an increase rate of 26 ind. $\mathrm{yr}^{-1}$ over the $15 \mathrm{yr}$ monitoring period. Temporal and seasonal fluctuations were observed, with the highest number of macaws recorded during rainy and non-breeding seasons. We discuss these results with an emphasis on the type of ranch management that favors the maintenance of hyacinth macaw food resources. The type of traditional cattle management used at the study site benefits both cattle production and macaw conservation due to positive interactions between cattle feeding habits and landscape-level management practices that preserve macaw habitat.
\end{abstract}

KEY WORDS: Long-term monitoring · Hyacinth macaw $\cdot$ Refuge habitat - Seasonal fluctuation · Roost site

\section{INTRODUCTION}

Historically, high levels of endemism, high biodiversity, and restricted distribution of species, at both the biome and niche scale, have been used to define priority areas for wildlife conservation (Vane-Wright et al. 1991, Kerr 1997, Watson et al. 2014). In addition to these parameters, refuges (defined as an 'area of land dedicated to the pro-

\footnotetext{
*Corresponding author: mceciliabt@gmail.com
}

tection and maintenance of biological diversity, and of natural and associated cultural resources, and managed through legal or other effective means' by Chape et al. 2003, p. 2) have been established to protect a vulnerable or threatened population from extinction. However, the effectiveness of these refuges in the conservation of minimumviable populations may be questionable because, over time, they undergo degradation within and

() The authors 2019. Open Access under Creative Commons by Attribution Licence. Use, distribution and reproduction are unrestricted. Authors and original publication must be credited. 
outside of the conservation area, mainly due to the effects of fragmentation, fire, soil degradation, and human encroachment (Scherer-Neto \& Toledo 2007, Taylor et al. 2012, Geldmann et al. 2013). As a result, the remaining populations may experience local extinction (Barlow \& Peres 2004, Recher et al. 2009). In regions where events that result in habitat degradation (such as fires) occur frequently, local populations seek out safe areas that provide a reliable supply of food and breeding sites (Robinson et al. 2014).

Gregarious behavior in birds leads to increased protection against predators and more efficient food acquisition (Ward \& Zahavi 1973, Beauchamp 1999). According to Munshi-South \& Wilkinson (2006), gregarious behavior and foraging may lead to a longer life span, especially for species that aggregate in roosts (Beauchamp 1999). Some juvenile and nonbreeding Psittacidae continue to use communal roosts during the non-breeding season. During the breeding season, breeding pairs of some species may remain in cavity nests in trees and ravines, e.g. Cape parrots Poicephalus robustus in South Africa (Wirminghaus et al. 2000), red-tailed parrots Amazona brasiliensis (Cougill \& Marsden 2004) and Lear's macaw Anodorhyncus leari in Brazil (Pacífico et al. 2014), and red-lored parrot Amazona autumnalis in Ecuador (Berg \& Angel 2006). This behavior makes it possible to monitor groups that are representative for the whole population, which is especially important for endangered species. Our assumption is that, in regions where factors affecting habitat degradation, such as fire, agriculture/livestock, and human occupation are intense, habitual overnight roosts can become important refuges for endangered bird species, and consequently such roosts become important monitoring areas for these species.

The hyacinth macaw Anodorhynchus hyacinthinus is the largest flying parrot species in the world, measuring up to $1 \mathrm{~m}$ of wingspan, with an average weight of $1300 \mathrm{~g}$ (Forshaw 1978, Sick 1997, Guedes 2009). Hyacinth macaws are a gregarious species generally found in pairs, families, or groups that vary from 3 to 100s of individuals, mainly in feeding and roost sites, and hyacinth macaws exhibit strong nesting, feeding, and roost-site fidelity (Guedes \& Harper 1995, Guedes 2009, Guedes \& Candisani 2011). Because of its characteristics and behavior, the hyacinth macaw is a charismatic and iconic species for biodiversity conservation (Guedes \& Candisani 2011). It has a wide geographic distribution, and over $95 \%$ of the population occurs in Brazil. The population is distributed in 3 non-contiguous areas:
(1) the Pantanal: Mato Grosso do Sul and Mato Grosso (see Fig. 1); (2) the northeastern region: Maranhão, Bahia, Piauí, Goiás, and Tocantins; (3) the Amazon region, in the states of Pará and Amapá (Guedes et al. 2008, Presti et al. 2015). Recently, this species has also been reported in the state of Amazonas (Barreiros \& Gomes 2010). Despite their wide distribution, Guedes et al. (2008) estimated the total wild population of hyacinth macaws at approximately 6500 individuals.

Due to large-scale captures for the wildlife tradeattractive for size, color and tolerance to human presence - and habitat degradation, including deforestation and fragmentation, the hyacinth macaw was included in the Convention on International Trade in Endangered Species (CITES) Appendices I and II, and has been listed as Vulnerable by the International Union for the Conservation of Nature since 1988 (IUCN 2014). In the last 25 years, there has been a significant increase in scientific knowledge about the genetics, nests, eggs, and chick management of this species, as a result of studies carried out by the Hyacinth Macaw Institute (Guedes \& Harper 1995, Faria et al. 2008, Allgayer et al. 2009, Guedes \& Candisani 2011, Marchesi et al. 2015, Presti et al. 2015). However, little is known about population fluctuations of hyacinth macaws and dynamics of the use of overnight roosts.

In July 1999, the World Wildlife Fund of Brazil (WWF-Brazil) carried out a workshop in the State of Mato Grosso, focused exclusively on hyacinth macaw conservation strategies, which included a visit to the São Francisco do Perigara ranch located in the Barão de Melgaço sub-region, in the northern Pantanal, Brazil. This ranch was chosen because it is the site of a traditional roost which has been used by hyacinth macaws for over $50 \mathrm{yr}$, and because of the abundance of the species in the area. According to censuses performed by the Hyacinth Macaw Institute, approximately $15 \%$ of the total population and $20 \%$ of the Pantanal population frequents the ranch (Guedes \& Candisani 2011). The presence of macaws at the ranch, and the finding by specialists that it could be one of the largest roost sites ever recorded, gave rise to the present research. Our hypothesis was that sustainable ranch management, which ensures food availability and protection against anthropogenic impacts, can result in an increase in the number of hyacinth macaws. Therefore, we aimed to quantify and study temporal fluctuations and seasonal changes through long-term monitoring of the number of hyacinth macaws, in order to understand the dynamics of roost-site use by the species. 


\section{MATERIALS AND METHODS}

\subsection{Study area}

The study was carried out on the São Francisco do Perigara ranch, located in the Barão de Melgaço sub-region, Pantanal wetland, Mato Grosso, Brazil $\left(16^{\circ} 54^{\prime} 16^{\prime \prime} \mathrm{S}, 56^{\circ} 15^{\prime} 33^{\prime \prime} \mathrm{W}\right)$ (Fig. 1). The property covers $289.95 \mathrm{~km}^{2}$ and the main economic activity is traditional, extensive cattle ranching.

Average cumulative rainfall in the area ranges from 1000 to $1500 \mathrm{~mm}$. during the rainy season (NovemberApril), and is less than $200 \mathrm{~mm}$ during the dry season (May-October). The average temperature in the region ranges from $21^{\circ} \mathrm{C}$ in the coldest month (July) to $29^{\circ} \mathrm{C}$ in the hottest month (January) (Alvares et al. 2013). During the rainy season, approximately onethird of the ranch is flooded, and thus inaccessible, due to overflow from the São Lourenço River. The other two-thirds of the ranch, including the ranch facilities area, is located on higher ground unaffected by flooding.
The vegetation in this region consists predominantly of savanna with dense, tall woodland (cerradão) and riparian forests along the Piquiri, São Lourenço, and Cuiabá rivers (Allem \& Valls 1987). The ranch landscape consists of a mosaic of forests and associated environments containing several types of palm trees, especially the acuri palm Scheelea phalerata and the bocaiuva palm Acrocomia aculeata, as well as natural grasslands in the 'Guatós indigenous' area, cultivated pastures consisting of exotic species, including signal grass Brachiaria decumbens, and natural grasslands degraded by human land use. The latter 2 landscape types occupy less than $2 \%$ of the ranch area. In sandy areas, there are some mono-specific vegetation types, predominantly consisting of canjiqueira Byrsonima orbygniana. The floodplain area is densely vegetated, and includes cambará Vochysia divergens and acuri and bocaiuva palm trees. In summary, nearly $32 \%$ of the study area consists of forests (cerradão, seasonal forest, and gallery forest), $35 \%$ of the area consists of open savanna, and the remaining area consists of open grasslands (wet and dry) and watercourses (Silva et al. 2000).
Fig. 1. São Francisco do Perigara ranch, located in the southeast of the State of Mato Grosso, Brazil. (Lower right) São Francisco do Perigara ranch area, in the Pantanal, Barão de Melgaço sub-region (shaded areas: tree cover/ wooded areas). Areas 1, 2, and 3 are hyacinth macaw roosting sites, and area 1 was the most commonly used by the macaws. Wide arrows: directions from which the macaws came to the roosting site, with the most common directions indicated by numbers $4,5,6$, and 7 ; thin arrows: macaws' movements before they settled at the roosting site for the night. Asterisks: point-count stations from which the observers carried out the macaw counts. The photo (lower left) shows the hyacinth macaws feeding on fruits of bocaiuva and acuri palm trees consumed and partially digested by cattle. Photo by Luciano Candisani

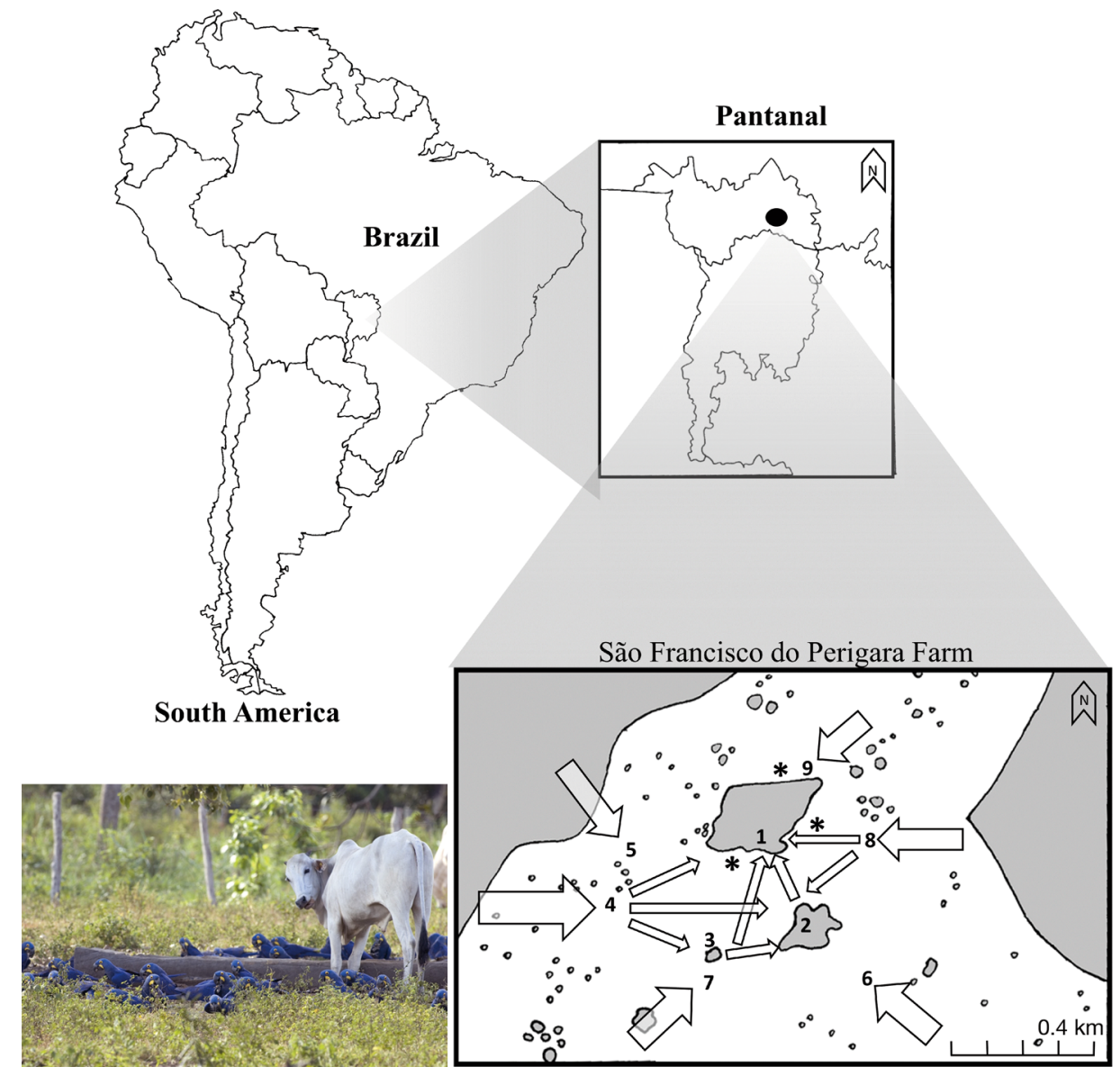




\subsection{Roost site}

The area around the ranch buildings consists mainly of open pastures, with large individual trees and forest fragments containing bocaiuva palm trees and other fast-growing plants recovering from past deforestation (Fig. 1). There are 2 areas in this landscape that serve as roost sites for hyacinth macaws: (1) an irregularly shaped forest fragment, which is a remnant consisting of $90 \%$ bocaiuva palm trees (Fig. 1, Area 1) with additional trees such as mangoes Mangifera indica, Indian almond Terminalia catappa, baru Dipteryx alata, and Brazilian copal Hymenaea courbaril. Over the years, this site has changed structurally as hyacinth macaws have destroyed the sprouts and leaves of the palm trees while roosting in the trees overnight and using them during the day to rest and eat. As the palm trees died, the macaws moved to other sites such as isolated trees or groups of bocaiuva palm near the ranch buildings. (2) An area with dozens of 'bocaiuva' palm trees found within $5 \mathrm{~m}$ of the farmhouse, which hyacinth macaws and other parrot species use to roost (Fig. 1, Area 2).

\subsection{Method for estimating the number of hyacinth macaws}

We developed survey methods based on the species' habit of flocking to collective roost sites. In the late afternoon, the macaws fly either in pairs or in groups from different areas of the ranch to a previously chosen place (Fig. 1). We counted hyacinth macaws at the roost site over a long period to monitor the number of hyacinth macaws, and to balance long-term temporal changes with seasonal fluctuations. Counts started in 2001 and continued until 2015, totaling 37 field visits, 18 of which were performed in the dry season and 19 in the rainy season. There were 19 visits in the breeding season (AugustJanuary) and 17 visits in the non-breeding season (February-July). Each visit had an overall duration of $3 \mathrm{~d}$ : $1 \mathrm{~d}$ to search for nesting pairs, and $2 \mathrm{~d}$ to visit the retreat areas and conduct 3 surveys at the roost during the afternoon. The roost surveys started at 16:00 h and ended shortly after dusk (approximately 19:30 h).

Before the counts, we carried out a preliminary count of hyacinth macaws that remained in wooded places near the ranch during the day. Once the number of hyacinth macaws near the ranch buildings was counted, a pair of observers went to each count station $(\mathrm{n}=3)$. Each observer team was equipped with binoculars (Nikon Action $8 \times 40 \mathrm{~mm}$ ), spotting scopes (Vollo VL-237), and chronometers. We selected the locations of point-count stations during the first year of sampling: these were located $800 \mathrm{~m}$ from the roost site and placed so as to reduce the bias of doublecounting (Fig. 1, Areas 2, 3 and 4). The observers simultaneously recorded the number of individuals (isolated or in groups) and the direction of flight. Many hyacinth macaws engage in short flights before perching in their chosen position at the roost. These short flights or movements (Fig. 1, thin arrows) were also recorded in terms of the number of individuals and direction of flight along trees (see Fig. 1, Areas: 1, 2, 3 and 4). The data were collected and standardized, taking into account entries and exits in order to avoid double-counting. For example, if 12 macaws entered the roost and 2 subsequently exited, the total number of macaws in the roost was counted as 10 .

Because the macaws tended to follow the cattle, some individuals remained in areas that were more distant from the roost. For this reason, we also conducted counts in different areas of the ranch, such as retreat spots away from the area surrounding the ranch buildings, and pastures with mineral salt troughs, where cattle gathered, attracting hyacinth macaws to feed (Fig. 1, lower left). We conducted direct counts of individual hyacinth macaws at 4 of these retreat spots. We also counted macaw pairs that remained in nests, although the known number of nests was small (see Table 1).

At the end of each sampling period 3 values were obtained: (1) the mean number of individuals at the roost site registered by the team at the roost site over $3 \mathrm{~d},(2)$ the total number of individuals in areas away from the roost (retreat spots with mineral/salt troughs), and (3) the number of macaw couples in the nests. Thus, the number of macaws on the ranch ('total number') was computed as the number of macaws in the roost + the number of macaws in retreat areas + the number of macaws in nests.

\subsection{Data analysis}

Results are reported as mean $\pm 95 \%$ confidence intervals (CI) for samples with $\mathrm{n}<30$. According to the results of the D'Agostino test for normality, we used a $t$-test, Mann-Whitney $U$-test, and KruskalWallis (KW) $H$-test for small sample sizes (n < 5), following Zwillinger \& Kokoska (1999). The statistical tests were used to compare data from the breeding season (August-January) and non-breeding season 
(February-July), as well as the dry (May-October) and rainy (November-March) seasons. All statistical analyses were conducted using GraphPad Prism v.7 software (GraphPad Software Inc.).

Precipitation is the environmental variable showing the strongest seasonality in the study region. To evaluate the effect of precipitation on the number of hyacinth macaws, we used data from a pluviometer installed at the ranch in 2002. We analyzed the relationship between the number of hyacinth macaws at the roost during each visit and the monthly mean precipitation using the Pearson linear correlation method.

To analyze trends regarding the number of hyacinth macaws during the study period, we used a linear regression model. The regression was conducted using the mean total number of individuals from years with $>2$ visits. A linear regression model was run using total numbers obtained in the months in which the ranch was most frequently visited, April ( $\mathrm{n}=7$ visits) and September ( $\mathrm{n}=6$ visits), and these months represent breeding and non-breeding periods, and rainy and dry seasons. We used the 'Trends \& Indices for Monitoring data' software package (TRIM version 3.53, Pannekoek \& Van Strien 2001) to calculate trends over time in the studied macaw group.

\section{RESULTS}

\subsection{Hyacinth macaw surveys}

Over the 15 yr of surveys on the ranch, the highest total numbers of hyacinth macaws were obtained in June 2013 and April 2015 (1042 and 1014 ind., respectively). The annual mean number of hyacinth macaws at the roost site varied significantly (KWtest, $H=30.74 ; \mathrm{p}<0.01$ ), and significant differences existed between 2007 and 2013 (diff. $=-26.33[62 \%$ ]; $\mathrm{p}<0.05$ ), and 2007 and 2015 (diff. $=-29.5[67 \%$ ]; $\mathrm{p}<$ 0.05) (Table 1).

Based on roost counts in the months with $>1$ visit, we found that the lowest mean number of individuals at the hyacinth macaw roost site was recorded in August ( $\mathrm{n}=3,116.2 \pm 61.3$ ) and the highest in April ( $\mathrm{n}=7 ; 357.4 \pm 185.2)$. However, variations in the number of macaws between months were not significant $(H=12.15$; $\mathrm{p}>0.05)$.

Over the 15 yr interval, the number of hyacinth macaws at the ranch showed an increasing trend. The model revealed that the total number of hyacinth macaws at the ranch increased by approximately
$37 \pm 7\left(\mathrm{r}^{2}=0.67 ; F_{(1,12)}=24.59 ; \mathrm{p}<0.0001 ; 95 \% \mathrm{CI}=\right.$ $12.5-44.7$ ), and the mean number of macaws at the roost site (Fig. 2, solid line) increased by approximately 28 ind. $\mathrm{yr}^{-1}\left(\mathrm{r}^{2}=0.55 ; F_{(1,12)}=15.09 ; \mathrm{p}<0.001\right.$; slope $=28.65 \pm 7.6 ; 95 \% \mathrm{CI}=21.1-54.3)$. According to TRIM analysis the increase was 24 ind. $\mathrm{yr}^{-1}\left(F_{(1,24)}=\right.$ $0.73 ; \mathrm{p}<0.05)$, which means a moderate increase in the total numbers of macaws during the studied period.

The model generated from surveys conducted in April $(n=7)$ and September $(n=6)$, using the mean number of individuals at the roost site (Fig. 2, dashed and dotted lines), revealed an increase in the number of hyacinth macaws over time. The number of hyacinth macaws recorded in April increased by $27 \pm$ 10 ind. $\left(\mathrm{r}^{2}=0.62 ; F_{(1,5)}=8.18 ; \mathrm{p}<0.05 ;\right.$ slope $=26.9 \pm$ 9.8) and the number of hyacinth macaws recorded in September increased by $37 \pm 11$ individuals over the same period $\left(\mathrm{r}^{2}=0.66 ; F_{(1,5)}=9.74 ; \mathrm{p}<0.05 ;\right.$ slope $=$ $37.1 \pm 11.9)$.

\subsection{Temporal and seasonal fluctuations}

Rainfall data showed that drier months to be May to August, with between 0 and $20 \mathrm{~mm}$ precipitation, and the wetter months to be November to April, with precipitation between 80 and $400 \mathrm{~mm}$ (Table 1). The number of hyacinth macaws was different ( $t$-test, $t=$ $2.063 ; \mathrm{p}<0.05$ ) between the rainy season (average rainfall in rainy months $=191.7 \mathrm{~mm}$; mean number of hyacinth macaws $=354.4$ ) and the dry season (average rainfall in dry months $=36.6 \mathrm{~mm}$; mean number

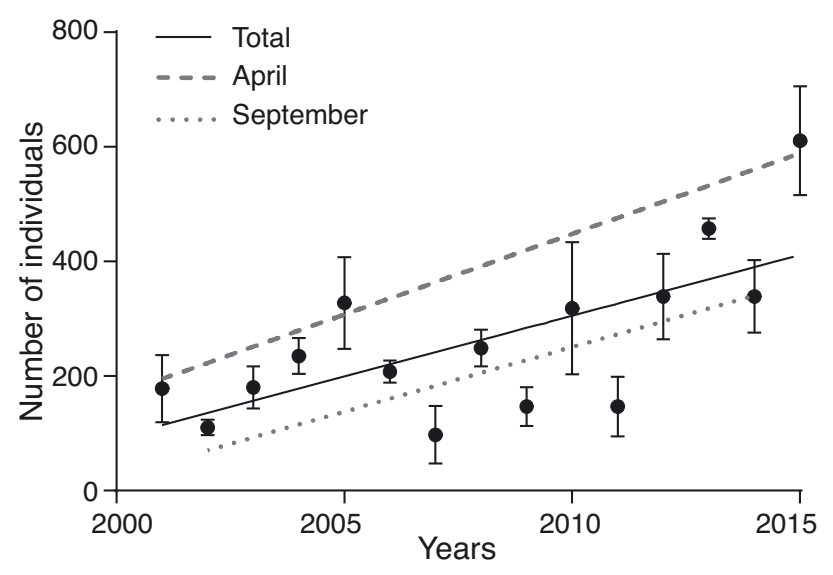

Fig. 2. Regression models between the number (mean $\pm \mathrm{SD}$ ) of hyacinth macaws on the São Francisco do Perigara ranch and the sampling years, from 2001 to 2015. The solid line shows the distribution of the mean number of macaws at the roost site by year. The dashed and dotted lines show the regression model in April and September, respectively 
of hyacinth macaws $=254.3$ ). This result was corroborated by the comparison between the most surveyed months, i.e. April (rainy) and September (dry) $(U=$ $6.0 ; \mathrm{p}<0.05$ ). Different patterns in seasonal variations were found in each year. In 2008, 2011, and $2015(\mathrm{p}<0.05)$ the greatest numbers of macaws were counted during the dry period, when mean monthly rainfall was below $100 \mathrm{~mm}$.
Precipitation during the study period was significantly and negatively correlated with the number of individual macaws in the roost $(\mathrm{r}=-0.64 ; \mathrm{p}<0.05$; $\mathrm{R}^{2}=0.41$ ). Breeding commences during the dry period (August). There were significantly more macaws on the ranch during the non-breeding season (mean $=319.7 \pm 105.7)$ than in the breeding (mean $=236.9 \pm$ 136.6) season $(U=80 ; \mathrm{p}<0.05$; Fig. 3).

Table 1. Number of hyacinth macaws registered in roost, retreat areas, and nests during the surveys on the São Francisco do Perigara ranch, Pantanal wetland, Mato Grosso, Brazil, from 2001 to 2015, based on total counts. Individuals (no. of nests in parentheses) refers to active nest with eggs, or chicks, or hyacinth macaw couples defending cavities. -: only one value, no mean available

\begin{tabular}{|c|c|c|c|c|c|c|c|c|}
\hline \multirow[t]{2}{*}{ Year } & \multirow[t]{2}{*}{ Month } & \multicolumn{2}{|c|}{ Mean precipitation (mm) } & \multicolumn{2}{|c|}{ No. of ind. in the roost -} & \multirow{2}{*}{$\begin{array}{l}\text { Retreat } \\
\text { areas }\end{array}$} & \multirow{2}{*}{$\begin{array}{l}\text { Individuals } \\
\text { (nest) }\end{array}$} & \multirow[t]{2}{*}{ Total } \\
\hline & & Annual & Monthly & Total & Annual mean $\pm 95 \%$ CI & & & \\
\hline \multirow[t]{4}{*}{2001} & Jan & & & 283 & $234 \pm 55$ & 40 & & 323 \\
\hline & Apr & & & 222 & & 93 & & 315 \\
\hline & Aug & & & 198 & & 68 & & 266 \\
\hline & Nov & & & 176 & & 59 & & 235 \\
\hline 2002 & Sep & 1254 & 90.0 & 120 & - & 33 & & 153 \\
\hline \multirow[t]{3}{*}{2003} & Jan & 1382 & 355 & 189 & $206 \pm 63$ & 18 & & 207 \\
\hline & Apr & & 89 & 266 & & 70 & & 336 \\
\hline & Aug & & 0 & 165 & & 109 & $2(1)$ & 276 \\
\hline \multirow[t]{3}{*}{2004} & Feb & 1277.5 & 355 & 263 & $257 \pm 59$ & $0^{\mathrm{a}}$ & & 263 \\
\hline & Jun & & 0 & 303 & & 80 & & 383 \\
\hline & Nov & & 135 & 206 & & 78 & 2 & 286 \\
\hline \multirow[t]{2}{*}{$2005^{b}$} & Feb & 1195.5 & 70 & 420 & $384 \pm 61$ & $0^{\mathrm{a}}$ & $12(6)$ & 432 \\
\hline & Apr & & 66 & 348 & & 32 & & 380 \\
\hline \multirow[t]{2}{*}{2006} & Apr & 1587.5 & 70.5 & 337 & $221 \pm 197$ & 42 & & 379 \\
\hline & Sep & & 134 & 106 & & 168 & & 274 \\
\hline \multirow[t]{3}{*}{2007} & Jun & 1364 & 0 & 136 & $133 \pm 67^{c}$ & 72 & $2(1)$ & 204 \\
\hline & Sep & & 50 & 76 & & 68 & & 144 \\
\hline & Nov & & 176 & 187 & & $6^{\mathrm{a}}$ & $22(11)$ & 215 \\
\hline \multirow[t]{3}{*}{2008} & Mar & 1129 & 162 & 244 & $272 \pm 47$ & 112 & 2 & 358 \\
\hline & Jul & & 0 & 300 & & 22 & & 322 \\
\hline & $\operatorname{Dec}^{\mathrm{d}}$ & & 52 & & & & $14(7)$ & \\
\hline \multirow[t]{2}{*}{2009} & May & 1107 & 38 & 249 & $221 \pm 47$ & 48 & & 297 \\
\hline & Sep & & 28 & 193 & & 58 & $6(3)$ & 257 \\
\hline \multirow[t]{2}{*}{$2010^{\mathrm{b}}$} & Jan & 755 & 147 & 400 & $364 \pm 61$ & 54 & $24(12)$ & 478 \\
\hline & Jun & & 0 & 328 & & 123 & & 451 \\
\hline \multirow[t]{3}{*}{2011} & Jan & 1290 & 395 & 315 & $245 \pm 204$ & 103 & $24(12)$ & 442 \\
\hline & Apr & & 80 & 369 & & 150 & & 519 \\
\hline & Aug & & 0 & 53 & & 380 & $40(20)$ & 473 \\
\hline \multirow[t]{3}{*}{2012} & Jan & 1277 & 134 & 334 & $391 \pm 60$ & 107 & $2(1)$ & 443 \\
\hline & Jun & & 37 & 424 & & 208 & & 632 \\
\hline & Sep & & 66 & 417 & & 122 & & 539 \\
\hline \multirow[t]{3}{*}{2013} & Apr & 977 & 20 & 371 & $572 \pm 228^{c}$ & 114 & $4(2)$ & 489 \\
\hline & Jun & & 0 & 745 & & 298 & & 1043 \\
\hline & Dec & & 130 & 600 & & $0^{\mathrm{a}}$ & $18(9)$ & 618 \\
\hline \multirow[t]{3}{*}{2014} & Jun & 1732 & 18 & 722 & $534 \pm 394$ & 120 & $4(2)$ & 846 \\
\hline & Sep & & 56 & 346 & & 65 & & 411 \\
\hline & $\operatorname{Dec}^{\mathrm{d}}$ & & 154 & & & & $14(7)$ & \\
\hline \multirow[t]{2}{*}{2015} & Apr & 1120 & 110 & 776 & $708 \pm 142^{c}$ & 234 & $4(2)$ & 1014 \\
\hline & Nov & & 168 & 640 & & 120 & $12(6)$ & 772 \\
\hline $\begin{array}{l}{ }^{a} \text { Flood } \\
\text { Guede } \\
\text { and } 20 \\
\text { et al. } 2\end{array}$ & $\begin{array}{l}\text { a where } \\
\text { Silva } 20 \\
\text { and } 2013\end{array}$ & $\begin{array}{l}\text { as not pos } \\
\text { Significa } \\
\text { ann's test }\end{array}$ & $\begin{array}{l}\text { o conduct } \\
\text { erences (K } \\
\text { 55). }{ }^{\mathrm{d}} \text { Surve }\end{array}$ & $\begin{array}{l}\text { surve } \\
\text { test, } H \\
\text { condu }\end{array}$ & $\begin{array}{l}\text { b. Installation of artificial } \\
26.3 ; p=0.015 \text { ) between } \\
\text { ted only of nests installed }\end{array}$ & $\begin{array}{l}\text { ts by the } \\
7 \text { and } 2 \\
\text { the Ara }\end{array}$ & $\begin{array}{l}\text { rara Azul In } \\
\text { (Dunn's tes } \\
\text { Azul Institut }\end{array}$ & $\begin{array}{l}\text { e (see } \\
28.33) \\
\text { uedes }\end{array}$ \\
\hline
\end{tabular}




\section{DISCUSSION}

\subsection{Hyacinth macaw population at the São Francisco do Perigara ranch}

According to our results, the total number of hyacinth macaws recorded on the São Francisco do Perigara ranch, in the Barão do Melgaço sub-region of the Pantanal wetland, was approximately 1000 in 2013 and 2015. This corresponds to $15 \%$ of the global population of hyacinth macaws (estimated at 6500 ind.; Guedes et al. 2008) and $20 \%$ of the Pantanal population (5000 ind.; Instituto Arara Azul 2017). This is the largest concentration of hyacinth macaws observed across the species' range, and the number of macaws on the ranch increased during the $15 \mathrm{yr}$ of monitoring. Our findings at this site show an encouraging and positive trend, unlike that found for many other psittacines. For example, the population of yellow-naped parrots Amazona auropalliata has declined by nearly $50 \%$ since 1980 because many of these birds are caught illegally for the pet trade (Dahlin et al. 2018). Marsden \& Royle (2015) carried out a survey of density and abundance changes among 356 parrot species. Results showed that protected areas and habitat degradation, mainly conversions from primary forest to anthropogenic habitat, were positively and negatively associated, respectively, with changes in abundance and density of parrots. Studies carried out in different parts of the world show that parrot populations have declined rapidly, mainly due to a lack of protected habitat (IUCN 2014, Birdlife 2015).

In terms of annual variation, the results indicate that during periods of heavy rain, macaws need to forage more broadly due to habitat flooding. Accord-

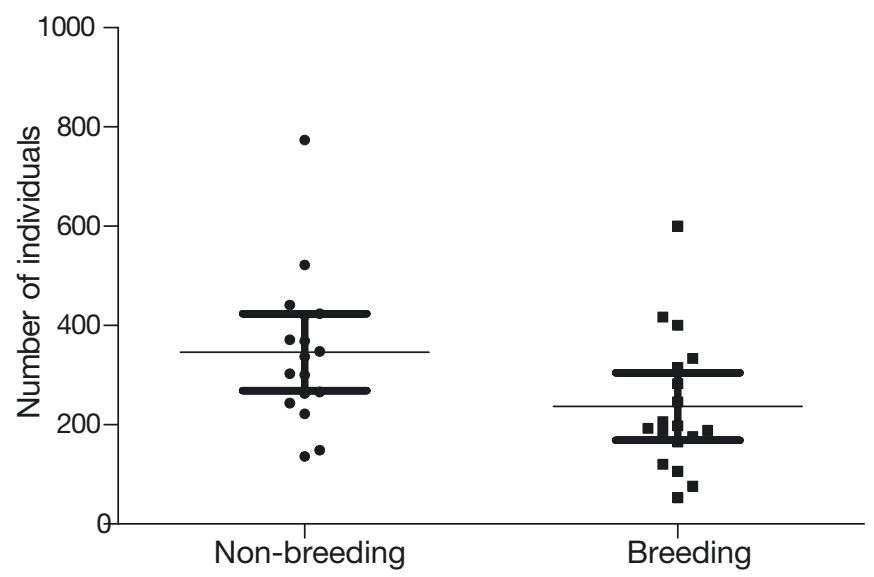

Fig. 3. Mean and $95 \%$ CI of the number of hyacinth macaws in the roost during the non-breeding and breeding seasons on the São Francisco do Perigara ranch, Brazil ing to Guedes (2009), during flooding in the Pantanal, there is a decrease in feeding areas for hyacinth macaws, which forage on the ground, forcing them to seek other sites in non-flooded areas on higher ground. This pattern of habitat use is further supported by the correlation between the number of individuals at the roost and precipitation data, especially during the drier years 2010-2013, during which we recorded greater numbers of hyacinth macaws. Guedes \& Harper (1995) observed the same trend when monitoring a small roost in the southern Pantanal.

The hyacinth macaw breeding season occurs predominantly between the months of August and January, although breeding may occur earlier or later in some years (Guedes 2009). Our results indicate that months with lower hyacinth macaw numbers coincided with the breeding season. However, there were few natural active nests in the study area (i.e. nests containing eggs and/or chicks), which could explain the variations observed within and among years. Our results indicate that hyacinth macaws can breed in areas that are outside the limits of the ranch. A study performed using radio telemetry showed that a juvenile macaw left the nest located $50 \mathrm{~km}$ away from the study area and flew to the Perigara roost along with other 90 macaws (Antas et al. 2010). The low number of active nests can likely be explained by scarcity of manduvi trees with suitable nesting cavities, which are used by hyacinth macaws for breeding, and where $95 \%$ of their nests are found (Guedes 1993, Pinho \& Nogueira 2003). Before the current owner acquired the ranch, the area was subject to fire and selective logging of trees. Currently, there are few manduvi trees in the area with natural cavities, and most of the available cavities are quickly occupied during the breeding season. The success of artificial nests corroborates our assumption that availability of suitable nest cavities has become a limiting factor for hyacinth macaw breeding in the study area (Guedes 1993, Martin et al. 2004, Aitken \& Martin 2008).

Our assumption was that the study area was predominantly used for feeding. According to Beauchamp (1999) roosting aggregations can increase food acquisition efficiency. This idea was further supported when the vegetation characteristics of areas surrounding the ranch buildings were observed. Acuri and bocaiuva palm trees are the most common tree species in the study area. Both species make up the hyacinth macaw's diet in the Pantanal (Guedes \& Harper 1995). These tree species are characterized as pioneer trees from secondary succession, and benefit 
from fire and degradation (Bicalho et al. 2016), which stimulate their growth and fruit production. The fruits of acuri and bocaiuva palm trees are consumed and digested by cattle, facilitating hyacinth macaw feeding (Pott \& Pott 1994, Guedes \& Harper 1995, Bicalho et al. 2016).

\subsection{Study area management and hyacinth macaw conservation}

The ranch's current management approach, with a very large area devoted to vegetation recovery, has helped to maintain food resources for the hyacinth macaws, which have used the property as a traditional feeding and roost site. In addition, with the support of Embrapa Pantanal and the Brazilian Association of Organic Cattle Ranching (ABPO), the ranch has implemented traditional extensive cattle management with a rotational grazing system in several paddocks. During the rainy season, the cattle are concentrated in a non-flooded, fenced area that favors the concentration of partially digested and excreted palm nuts that macaws feed on. As a result, the macaws gather during the flood season, following the cattle (Guedes 1993, Yamashita 1997). Hence, the availability of food resources contributes to an increase in the number of hyacinth macaws, and the cattle management dynamic helps to explain the variation observed between dry and rainy periods.

Safety was likely another important factor for this choice of roost site. The hyacinth macaws were not disturbed on the ranch because there were few employees and limited activity. There were no freeranging pets such as cats and dogs, which could disturb the macaws when they land to feed on nuts. In the Pantanal, the association between wildlife conservation and cattle ranching is evident. Ranches play a key role in biodiversity conservation by keeping areas safe from illegal hunters. Native species benefit from this protection, and many ranches have become refuges for large wildlife populations, in many cases becoming more effective than some state or federal protected areas (Silva \& Strahl 1991, Hoogesteijn \& Hoogesteijn 2010). For over 50 yr, the São Francisco do Perigara ranch has been protected from forest fires and deforestation, thus helping to maintain resources for hyacinth macaws, such as food and roost sites. These resources are important factors in preserving the macaws in the region.

It is important to emphasize that the São Francisco do Perigara ranch has a management philosophy that encourages the macaws to live in relative harmony with cattle ranching, and the macaw population appears to be growing, either through reproduction, immigration, or a combination of both. The traditional management practiced on the ranch takes into account the care and conservation of important areas for wild fauna (for instance, the ranch includes a fenced forest fragment that has served as a roost site for hyacinth macaws for over half a century), the protection of specific tree species, as well as the rotational grazing system over several paddocks. This strategy is consistent with the natural pasture cycle due to the rainy and dry seasons, and provides a refuge habitat for the hyacinth macaws and other Pantanal fauna species, which are also threatened with extinction, such as the spotted jaguar Panthera onca and the maned wolf Chrysocyon brachyurus.

Acknowledgements. Special thanks to Maria Bernadete Ribas Lange for her immediate support for this research through the WWF Brasil Pantanal program; to Francisco Barretto, for support during the beginning of the study, and to the sisters Ana Maria Barros and Maria Ignez Marcondes Barreto, owners of the ranch, for their encouragement and support for the macaw surveys; to several employees, especially to 'Pixico' - Gonçalo Rodrigues da Silva. We thank the different teams who participated in each visit, including Eduardo Carrano, Cassiano Fadel Ribas, Yara Melo Barros, Carlos Bianchi, Arthur Bispo de Oliveira, Carolina Coelho Scherer, Antenor Silva Júnior, André Pelanda, Raphael F. Santos, Eduardo Patrial, Louri Klemann Júnior, Tiago Venâncio, Carlos Pedroso, Mariângela Allgayer, Marcelo Allgayer, Mathias Dislich, Fabiane G. Schimidt, Valdi P. Gonçalves, Eduardo B. Cunha, Leverci Silveira Filho, Luciana Chyio, Ildo Ritter de Oliveira, Jonas Kilp, Patrick I. Pina, Leonel Andermann, Tony Bichinsky, Adriano Travassos, Gledson Bianconi, Bruno H. Carvalho, Romulo Cícero Silva and Solange Latenek. We appreciate the support and presence of Anna Croukamp (Parque das Aves). We also thank Dr. Luciano Sabóia and the Hyacinth Macaw Institute, who provided the installation of artificial nests for the hyacinth macaws on the São Francisco ranch. The ITA thanks Carlos Cézar Corrêa, Grace Ferreira da Silva, Edson Diniz Lino Pereira, Fernanda Fontoura, Luciana Ferreira, Cynthia Mazzi and Fundação Toyota. We thank Leonie Seabrook, $\mathrm{PhD}$, for editing a draft of this manuscript. We appreciate reviews of this paper by Thomas H. White Jr., $\mathrm{PhD}$, of the US Fish and Wildlife Service's Puerto Rican Parrot Recovery Program, Paul R. Reillo, PhD, of the Rare Species Conservatory Foundation and Walfrido M. Tomas, PhD, Embrapa Pantanal.

\section{LITERATURE CITED}

Aitken KEH, Martin K (2008) Resource selection plasticity and community responses to experimental reduction of a critical resource. Ecology 89:971-980

Allem AC, Valls JFM (1987) Recursos forrageiros do Pantanal mato-grossense. Documentos da Embrapa 8. Embrapa, Brasília 
Allgayer MC, Guedes NMR, Chiminazzo C, Cziulik M, Weimer TA (2009) Clinical pathology and parasitologic evaluation of free-living nestlings of the hyacinth macaw (Anodorhynchus hyacinthinus). J Wildl Dis 45:972-981

Alvares CA, Stape JL, Sentelhas PC, de Moraes Gonçalves JL, Sparovek G (2013) Köppen's climate classification map for Brazil. Meteorol Z (Berl) 22:711-728

Antas PTZ, Carrara LA, de Souza Yabe R, Ubaid FK, de Oliveira-Júnior SB, Vasques ER, Ferreira LP (2010) A arara-azul na Reserva Particular do patrimônio natural SESC Pantanal. Conhecendo o Pantanal 6. SESC, Departamento Nacional, Rio de Janeiro

Barlow J, Peres CA (2004) Avifaunal responses to single and recurrent wildfires in Amazonian forests. Ecol Appl 14: 1358-1373

Barreiros MHM, Gomes FBR (2010) First record of hyacinth macaw Anodorhynchus hyacinthinus (Latham, 1790) for the state of Amazonas, Brazil. Rev Bras Ornitol-Braz J Ornithol 18:336-337

Beauchamp G (1999) The evolution of communal roosting in birds: origin and secondary losses. Behav Ecol 10:675-687

* Berg KS, Angel RR (2006) Seasonal roosts of red-lored amazons in Ecuador provide information about population size and structure. J Field Ornithol 77:95-103

Bicalho EM, Rosa BL, Souza AE, Rios CO, Pereira EG (2016) Do the structures of macaw palm fruit protect seeds in a fire-prone environment? Acta Bot Bras 30:540-548

Birdlife International (2015) http://datazone.birdlife.org/ home (accessed 15 January 2016)

Chape S, Blyth S, Fish L, Fox P, Spalding M (2003) United Nations list of protected areas. IUCN, Gland and UNEPWCMC, Cambridge

Cougill S, Marsden SJ (2004) Variability in roost size in an Amazona parrot: implications for roost monitoring. J Field Ornithol 75:67-73

Dahlin CR, Blake C, Rising J, Wright TF (2018) Long-term monitoring of yellow-naped amazons (Amazona auropalliata) in Costa Rica: breeding biology, duetting, and the negative impact of poaching. J Field Ornithol 89:1-10

Faria PJ, Guedes NM, Yamashita C, Martuscelli P, Miyaki CY (2008) Genetic variation and population structure of the endangered hyacinth macaw (Anodorhynchus hyacinthinus): implications for conservation. Biodivers Conserv 17:765-779

Forshaw JM (1978) Parrots of the world, 2nd edn. David \& Charles, Newton Abbot

* Geldmann J, Barnes M, Coad L, Craigie ID, Hockings M, Burgess ND (2013) Effectiveness of terrestrial protected areas in reducing habitat loss and population declines. Biol Conserv 161:230-238

Guedes NMR (1993) Biologia reprodutiva da arara azul (Anodorhynchus hyacinthinus) no Pantanal - MS, Brasil. MSc thesis, University of São Paulo

Guedes NMR (2009) Sucesso reprodutivo, mortalidade e crescimento de filhotes de araras azuis Anodorhynchus hyacinthinus (Aves, Psittacidae) no Pantanal Brasil. PhD thesis, São Paulo State University, São Paulo

Guedes NMR, Candisani L (2011) Jóias azuis no céu do Pantanal: a história do Projeto Arara Azul, que está ajudando na conservação da biodiversidade-Blue jewels across the Pantanal skies: the history of the Hyacinth Macaw Project, which is helping conserve biodiversity. DBA, São Paulo

Guedes NMR, Harper LH (1995) Hyacinth macaw in the Pantanal. In: Abramson, J, Speen BL, Thonsem JB (eds)
The large macaws: their care, breeding, and conservation. Raintree Publications, Fort Bragg, CA, p 394-421

Guedes NMR, Silva GF (2010) Instalação de ninhos artificiais na fazenda São Francisco do Perigara. Relatório técnico do Projeto Arara Azul. Instituto Arara Azul, Campo Grande

Guedes NMR, Bianchi CA, Barros Y (2008) Anodorhynchus hyacinthinus. In: Machado, ÂBM, Drummond GM, Paglia AP (eds) Livro vermelho da fauna Brasileira ameaçada de extinção, 1st edn. Ministério do Meio Ambiente, Brasilia, p 467-468

Guedes NMR, Fontoura FM, Pereira ELD, Vicente E and others (2014) Relatório anual de atividades do Projeto Arara Azul. Instituto Arara Azul, Campo Grande

Hoogesteijn A, Hoogesteijn R (2010) Cattle ranching and biodiversity conservation as allies in South America's flooded savanna. Great Plains Res 20:37-50

Instituto Arara Azul (2017) Annual report. www.projeto araraazul.org.br

IUCN (International Union for Conservation of Nature and Natural Resources) (2014) Anodorhynchus hyacinthinus www.iucnredlist.org/species/22685516/93077457 (accessed 19 February 2015)

Kerr JT (1997) Species richness, endemism, and the choice of areas for conservation. Conserv Biol 11:1094-1100

Marchesi MD, Rossi JL, Guedes NMR, Carneiro MTWD, Endringer DC, Camargo Filho CB (2015) Relationship between weight, age and hatching success and the concentration of heavy metals in nestling blue macaw (Anodorhynchus hyacinthinus Latham, 1790) in the Pantanal, Mato Grosso do Sul. Pesqui Vet Bras 35:569-572

*Marsden SJ, Royle K (2015) Abundance and abundance change in the world's parrots. Ibis 157:219-229

* Martin K, Aitken KEH, Wiebe KL (2004) Nest sites and nest webs for cavity-nesting communities in interior British Columbia, Canada: nest characteristics and niche partitioning. Condor 106:5-19

*Munshi-South J, Wilkinson GS (2006) Diet influences life span in parrots (Psittaciformes). Auk 123:108-118

*Pacífico EC, Barbosa EA, Filadelfo T, Oliveira KG, Silveira LF, Tella JL (2014) Breeding to non-breeding population ratio and breeding performance of the globally Endangered Lear's macaw Anodorhynchus leari: conservation and monitoring implications. Bird Conserv Int 24:466-476

Pannekoek J, Van Strien AJ (2001) TRIM 3 Manual (TRends \& Indices for Monitoring data). Statistics Netherlands, Voorburg

Pinho JB, Nogueira FMB (2003) Hyacinth macaw (Anodorhynchus hyacinthinus) reproduction in the northern Pantanal, Mato Grosso, Brazil. Ornitol Neotrop 14:29-38

Pott A, Pott VJ (1994) Plantas do Pantanal. Embrapa Pantanal, Corumbá

*PPresti FT, Guedes NMR, Antas PTZ, Miyaki CY (2015) Population genetic structure in hyacinth macaws (Anodorhynchus hyacinthinus) and identification of the probable origin of confiscated individuals. J Hered 106:491-502

Recher HF, Lunney D, Matthews A (2009) Small mammal populations in a eucalypt forest affected by fire and drought. I. Long-term patterns in an era of climate change. Wildlife Res 36:143-158

Robinson NM, Leonard SWJ, Bennett AF, Clarke MF (2014) Refuges for birds in fire-prone landscapes: the influence of fire severity and fire history on the distribution of forest birds. For Ecol Manage 318:110-121

Scherer-Neto P, Toledo MCB (2007) Avaliação populacional 
do papagaio-de-cara-roxa (Amazona brasiliensis) (Psittacidae) no Estado do Paraná, Brasil. Ornitol Neotrop 18: 379-393

Sick H (1997) Ornitologia brasileira. Nova Fronteira, Rio de Janeiro

Silva JL, Strahl SD (1991) Human impact on populations of chachalacas, guans, and currassows (Galliformes: Cracidae) in Venezuela. In: Robinson JG, Redford KH (eds) Neotropical wildlife use and conservation. University of Chicago Press, Chicago, IL, p 37-52

Silva MPD, Mauro R, Mourão G, Coutinho M (2000) Distribuição e quantificação de classes de vegetação do Pantanal através de levantamento aéreo. Rev Bras Bot Braz J Bot 23:143-152

Taylor RS, Watson SJ, Nimmo DG, Kelly LT, Bennett AF, Clarke MF (2012) Landscape-scale effects of fire on bird assemblages: Does pyrodiversity beget biodiversity? Divers Distrib 18:519-529

Editorial responsibility: Michael Reed, Medford, Massachusetts, USA
Vane-Wright RI, Humphries CJ, Williams PH (1991) What to protect? - Systematics and the agony of choice. Biol Conserv 55:235-254

* Ward P, Zahavi A (1973) The importance of certain assemblages of birds as 'information-centres' for food-finding. Ibis 115:517-534

* Watson JEM, Dudley N, Segan DB, Hockings M (2014) The performance and potential of protected areas. Nature 515:67-73

Wirminghaus JO, Downs CT, Symes CT, Perrin MR (2000) Abundance of the Cape parrot in South Africa. S Afr J Wildl Res 30:43-52

Yamashita C (1997) Anodorhynchus macaws as followers of extinct megafauna: a hypothesis. Rev Bras Ornitol-Braz J Ornithol 5:176-182

Zwillinger D, Kokoska S (1999) CRC standard probability and statistics tables and formulae. CRC Press, Boca Raton, FL

Submitted: November 27, 2017; Accepted: February 28, 2019 Proofs received from author(s): April 30, 2019 